\title{
The Effect of Parenting Styles for Children's Behaviour on Using Gadget at Revolution Industry
}

\author{
Avanti Vera Risti Pramudyani $\otimes_{1}$ \\ Pendidikan Anak Usia Dini, Universitas Ahmad Dahlan \\ DOI: $\underline{10.31004 / \text { obsesi.v5i1.520 }}$
}

\begin{abstract}
This study aims to know of understanding of authoritative parenting style and affected the children behaviour while using a gadget. This is qualitative with data collection from an interview, observation, and document. Analysis of the data used by Miles and Huberman. The subject is parent's and their children lived at Yogyakarta. This result is the parents with authoritative parenting can classify, analyze, comparing, and evaluate their parenting style. With those understanding gives the effect on children when the children used gadget at home such as show discipline and follow the parent's rules; the children have critical thinking and independent using the gadget. Even though authoritative parenting identical with gives freedom, they have to give limit time for children to use a gadget, $6-7$ hours in a week. Another recommendation does not give the children a gadget even though a gadget is one of the basic need for communication.
\end{abstract}

Keywords: parenting style; children behaviour; gadget.

\begin{abstract}
Abstrak
Penelitian ini bertujuan untuk mengetahui pemahaman orangtua tentang pola asuh otoritatif dan efeknya dalam perilaku penggunaan gawai pada anak. Penelitian ini menggunakan pendekatan penelitian kualitataif deskriptif dengan pengumpulan data dari wawancara, observasi, dan dokumentasi. Analisis data dalam penelitian ini menggunakan Miles dan Huberman. Subjek penelitian ini adalah orangtua dengan pola asuh otorittaif dan anak usia dini yang tinggal di Yogyakarta. Hasil penelitian menunjukkan bahwa tingkat pemahaman orangtua dengan pola asuh otoritatif yaitu mampu mengklasifikasikan, menganalisis, membandingkan, dan mengevaluasi pola asuh yang dilakukan. Pemahaman tersebut berpengaruh pada penggunakan gawai anak dirumah dengan menunjukkan sikap disiplin dan mentaati aturan, anak dapat berpikir kritis dan mandiri saat menggunakan. Meskipun orang tua diharapkan memberikan durasi waktu yang sesuai dengan umur perkembangan anak yaitu $6-7$ jam selama satu minggu. Selain itu diharapkan tidak memberikan gawai sejak dini kepada anak meskipun trend gawai adalah salah satu kebutuhan sehari-hari sebagai alat komunikasi.
\end{abstract}

Kata Kunci: pola asuh, perilaku anak, gawai.

Copyright (c) 2019 Avanti Vera Risti Pramudyani

$\triangle$ Corresponding author:

Email Address : avanti.pramudyani@pgpaud.uad.ac.id ( Yogyakarta, DIY )

Received 20 April 2020, Accepted 25 April 2020, Published 25 April 2020 


\section{INTRODUCTION}

Revolution industry begins in the 17th Century with innovation on water and steam power, also mechanization. Today, the society facing revolution industrial 4.0 with a cyberphysical system, internet of things, autonomous robots, and internet service. According to (Schumacher, A., Erol, S., \& Shin, 2016), Revolution Industry 4.0 is surrounded by a huge network of advanced technologies across the value chain. Service, Automation, Artificial Intelligence Robotics, Internet of Things and Additive. For instance, every human activity using the internet to make their business more convenient, from the professional area until the domestic area. For instance, every human activity using the internet to make their business more convenient, from the professional area until the domestic area. Even today, an Indonesian citizen as the biggest user internet in South East Region with the number of the user 171 million peoples have the slogan everything at our hand (Pratomo, 2019).

The Advancement of Information Technology (IT) helps humans to create, modify, store, communicate or disseminate information. Information technology brings together high-speed computing and communications for data, voice and video. The gadget has a common sense as an electronic device that has a special function on each device such as (a) Handphone, (b) Smartphone, (c) Netbook, (d) Tablet, (Laptop). One of the rapid progress of information technology is the development of gadget media. Gadgets are very important for human life to communicate, multiply relationships, add insight and knowledge, education, and business. However, on the other hand, the opposite is caused by the inaccuracy factor of the wearer or less in utilizing the actual function (Sa'ad, 2015).

(Setiawati, Eka, Sohihatulmillah, Elih, Cahyono, Habib, 2018), confirms that the use of gadgets for early childhood should be limited, children aged 0-2 years should not introduce the gadget while the age of 3-5 years is limited to one hour per day and for children aged 618 two hours a day. The proper use of gadgets in early childhood is by limiting the time and introducing the game's gadgets and applications that are appropriate and suitable with the age stage of child development. The use of excessive gadgets in early childhood will certainly give a negative effect on the growth of children because they can be addictive, which can lead to dependence or addictions in children. Usually children using gadget to interact with social media, they used social media much better than the parents.

Social media users in Indonesia not only the adults but also children, they used social media a lot more than their parents. It is strengthened by the research result from $(M, 2018)$, kids using a gadget with purpose playing games, watching videos, listening to songs, chatting with their friends, and browsing the different website. Parents can prevent the children to use the internet or access social media when they doing nurturing the children. According to (Baumrind, 1966), there is the parental style that parents can use to nurturing the children such as authoritarian, authoritative, and permissive.

Every parenting style has different characters and purposes. The authoritative parenting style has characteristics guidance their children on issue-oriented and rational manner. The parents use effective communication and relationship when interacting with their children. This parenting style will influence the children to develop their level of selfreliance, self-esteem and ability to employ effective coping strategies while developing a positive self-image. For the authoritarian parenting style, the parents will be so shape and control the children's attitudes with the standard of conduct, children are supposed to follow very strictly. The children will get punishment if the failed the rules. This parenting style can make the children's ability and self-confidence lower when they become adolescents and they will depend to make social interaction. While parents with permissive parenting styles, they attempt to behave in an acceptant, affirmative and non-punitive manner toward their children's impulses, actions and desires. Parents have a level responsive higher level and encouraging children when they become adults as a resource (Baumrind, 1966). For early childhood, parenting style can impact their aspect development. 
The parenting style that parents choosing to nurture their children will have an effect on childhood development. According to (Hasanah, Nur \& Sugito, 2020), parents with permissive parenting will cause to make the children become speech delays, it because of the parents busy; lack stimulation, interaction and positive environment; and the parents desire that not fit with their environment. In line with the result of research from (Vega, De Asla; Hapidin; \& Karnadi, 2019), parenting style has a positive correlation with confident on the children, if the parents give verbal violence to the children, it will be effected to the children's confidence. As parents, it is important to choose the parenting style that can developing aspect of children and build positive behaviour.

Parenting style are important for early childhood education to helps them broaden the child's horizon, enchance social relationship, also promote a sense of self esteem and self efficacy. parenting style is important for early childhood education to helps them broaden the child's horizon, enhance the social relationship, also promote a sense of self-esteem and self-efficacy. For instance, children will be performed better when their parents can be involved in the school program. It means that if the parents have shown their support both at school and home as their children will get the better achievement on the academic aspect. The parent's origin, from the urban or rural area, does not have the impact as long as they support their children, because parenting style came from their thought (Rogers, Maria, A., Theule J., Ryan Bruce A., Adams G. R., 2009).

(Jahja, 2015) reveals authoritative parenting is a nurturing that shows loving and perceptive expressions of the children's needs and able to develop good communication patterns early on and encourage more mature children In achievement and apply the restrictions that children can do. The caregiving does not recognize the name of the power of parents such as jerking and hitting the child, putting forward the power and role of unvisible parents in an authoritative foster pattern are all more democratic. The authoritative foster pattern called a democratic foster pattern is a foster pattern that balances the demands and responsibilities or responsiveness between parents and children. The authoritative foster pattern emphasizes controlled freedom in shaping child behaviour. The foster pattern gives children the opportunity to be independent to do all their activities under the supervision and direction of the parents.

Authoritative parents have a similar understanding of the obligations and rights between parents and children. Gradually the parents were always dialogues and gave responsibility for his children. The authoritative upbringing is characterized by the condition that children are given the opportunity to be independent and develop their internal controls, the child is acknowledged to be in existence by parents, children are involved in decision making. Authoritative parents also always pay attention to the development of the child, and not only be able to advise and advise but also willing to listen to children's complaints related to problems. The authoritative foster pattern allows all decisions to be the decision of children and parents (Mensah, Monica Konnie \& Kuranchie, 2013).

The parenting style that the parents do have an effect on children's performance at school according to (Paler, Juvert N., Batiller, Kenneth B., \& Valiente, 2019), authoritative parenting has correlated with educational achievement of students at school, with this parenting style parents show their support for children on academic or any activities at school. Authoritative parenting style can be the recommendation for parents for nurturing children in modern society, the parents can encourage children who have a lot of activities to developing their competencies for response revolution industry.

Modern parents in revolution industry cannot avoid technology developing such as the internet or social media. However, they should make consideration for the children in using the internet and social media wisely. This study wants to know the parenting style that they used to nurture the children and the impact on children as user internet or social media. 


\section{METHODS}

This research is a type of research with a qualitative and descriptive approach aimed at describing the parental style from the parents from the knowledge of foster patterns conducted during the childcare process. The qualitative approach was chosen as a research methodology with the aim that researchers get an in-depth look at the knowledge, understanding, and application of foster pattern by parents.

Data collected from an interview, observation and documentation. Technical analysis of data in this study uses data considerations, data presentation, and withdrawal of conclusions. In accordance with the opinions of data analysis in the first phase is the consideration of data by conducting data selection, focusing the data needed according to the formulation, simplifying data, conducting traction, and analyzing data. Furthermore, the result data is performed data presentation through organizing data by summarizing data based on information in accordance with reflection analysis and action. The last stage is describing the results and drawing conclusions (Miles, M. B., Huberman, M. A., \& Saldana, 2014).

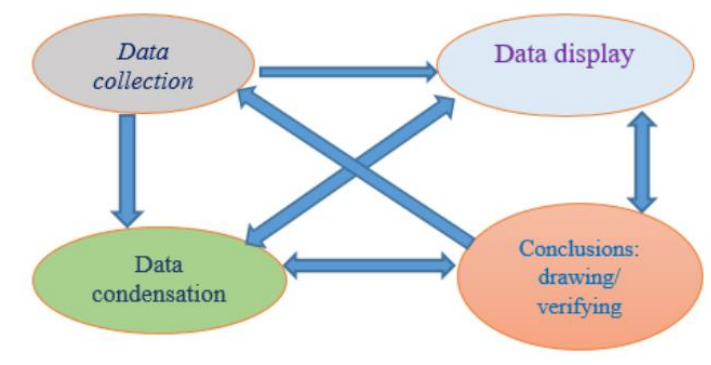

Picture 1. Analysis Data

(Miles, M. B., Huberman, M. A., \& Saldana, 2014)

This study involved 12 parents who had children aged 3 - 5 years, domiciled in Yogyakarta city, and used authoritative parenting style. Researchers also involve children from parents who are subject to research.

The study focuses on a parental knowledge level consisting of knowledge, understanding, and the application of foster care to the child. Qualitative data obtained is analyzed to obtain an overview of the level of parental knowledge. In addition, researchers will see an overview of the use of gadgets in children based on time duration.

\section{RESULT AND DISCUSSION}

Results obtained from the collection of data in the form of an interview to parents in the area of Yogyakarta City. The participants in this research used authoritative parenting to nurturing the children, even they have a different standard to implement. Information about parenting style came from an interview with all participants using guidelines. These research also obtained information through observation to get information about the behaviour of children when they used the gadget. Completing the data in this research collect from documentation such as photo, video, and parent's rule about using the gadget.

The data had have collected from interview, observation, and document coded and obtained to know the level of knowledge of parents in the aspect of knowledge, understanding and implementation is divided into three levels namely high, moderate, and low. In this article only focus on the higher level of parent's understanding. The basis of classifying the levels is based on the results of the collection of data that parents do without looking at the background of education, economics, social status, or age.

Participants used authoritative parenting in all levels had the same reason, they have perceptions this parenting style lead the children in positive. For example, the belief the children will be developing more independent, discipline, and get higher achievement better 
than the other. The participants also mentioned authoritative parenting gives the children to feel free but still have to control them. They said with this parenting style the communication between parents and children more effective because they learn to be a good listener. However, from all participants, the low level seems implemented the authoritative parenting have to improve. According to (Novilia, E., Murwani, D., \& Indrawati, 2016), authoritative parenting gives freedom to the children under supervisor and with that parenting style make a positive impact for children character such as independent, confident, outgoing and visioner - having a future orientation.

Differences between the implementations of authoritative parenting depend on the level of understanding of the participants. If the participants have a high level of knowledge and understanding they will implement their parental style with respected the children. For instance, participants with a high level of authoritative parenting the children's behaviour more behave while used gadget. It is strengthened by the research result from (Sarwar, 2016), authoritative parenting style is effective for children's behaviour if the parents spend more time with their children, furthermore, the children have a higher probability to develop the delinquent behaviour. It is shown parenting style can cultivated character for children more effective.

Table 1. The Higher Level Parent's On Authoritative Styles

\begin{tabular}{|c|c|c|}
\hline $\begin{array}{l}\text { Level of the } \\
\text { Parents }\end{array}$ & Parent's Understanding & $\begin{array}{l}\text { Child's Behaviour } \\
\text { Using Gadget }\end{array}$ \\
\hline \multirow{5}{*}{$\begin{array}{l}\text { Level } \\
\text { Knowledge }\end{array}$} & $\begin{array}{l}\text { They can explain and give the indication clearly and } \\
\text { systematically the content of authoritative parenting }\end{array}$ & \multirow{4}{*}{$\begin{array}{l}\text { They used the } \\
\text { gadget for six until } \\
\text { seven hours every } \\
\text { week, on Saturday } \\
\text { and Sunday }\end{array}$} \\
\hline & They can construct the purpose of authoritative parenting & \\
\hline & They can mention the benefit of authoritative parenting & \\
\hline & $\begin{array}{l}\text { They can give the illustration in real life to nurturing the } \\
\text { children with authoritative parenting }\end{array}$ & \\
\hline & $\begin{array}{l}\text { They can say the terminology of authoritative parenting in } \\
\text { Bahasa and English }\end{array}$ & \multirow{4}{*}{$\begin{array}{l}\text { The application } \\
\text { that children used } \\
\text { provided from the } \\
\text { parents. }\end{array}$} \\
\hline \multirow{4}{*}{$\begin{array}{c}\text { Level } \\
\text { Understandi } \\
\text { ng Parents }\end{array}$} & They can classified their parenting style & \\
\hline & They can analysis what they do as parents & \\
\hline & They can comparing the parenting style with another style & \\
\hline & They can evaluate tl & \multirow{4}{*}{$\begin{array}{l}\text { The application: } \\
\text { Youtube, game, } \\
\text { Barbie, and cartoon } \\
\text { The gadget: laptop } \\
\text { and smartphone }\end{array}$} \\
\hline \multirow{3}{*}{$\begin{array}{c}\text { Level } \\
\text { Implementat } \\
\text { ion Parents }\end{array}$} & The parents $\mathrm{g}$ & \\
\hline & $\begin{array}{l}\text { The parents refracted the children to independent and } \\
\text { discipline }\end{array}$ & \\
\hline & $\begin{array}{l}\text { The interactivity between parents and children: eye contact, } \\
\text { hungging, listening, and give some advice }\end{array}$ & \\
\hline
\end{tabular}

(Source: An Interview, observation and documentation from participants)

Based on table 1. the classification of the higher-level understanding can develop discipline for the children while using the gadget. On that table shows the higher-level understanding consist of knowledge, understanding and implementation, the participants can explain more details about all the aspect of authoritative parenting. From the level of knowledge, the participants can describe the definition of authoritative parenting such as the indication, content, purpose, benefit, illustration and terminology. On the level understanding, the participants can classified, analysis, comparing and evaluate their parenting style at authoritative parenting. For the implementation of authoritative parenting can show that the participant knew how to respond to their children. Those level of understanding builds the children's behaviour to obey the parents rule. The children have more respect for their parents, it shows when they used gadget only at the weekend, with a minimum hour and application that the parents provide. In line with (Bibi, F., Chaudhary, A. G., \& Tariq, 2013), authoritative parenting give positive influence for life domain children such as education and psychological wellbeing. According to (Shikret, R., \& Vecchiotti, 1997), 
parents with authoritative parenting style will gained behaviour for children more cosistent in discipline.

The participants know that discipline not only give the strict rule for the children when they do something, discipline at the authoritative parenting means that the parents provide some rule but still to make sure the children can get the meaning of the actions. From the (Baumrind, 1966), authoritative parenting has two types disciplinary and nondisciplinary, event those types look like different but they have similar concepts, the parents have aimed to control, manage or regulating child behaviour, give the suggestion, and guidance the children. The different from this type is if the discipline combines positive and negative parenting practises, also high support and have a high rule setting. On the other side, the non-discipline only used positive parenting practices high support and high rule setting.

The level of understanding about authoritative parenting from the participants also shows when they give the illustrations about how they nurturing the children. They give information about the rules that they used to the children, for instance, time to the used gadget and the reason why they used the rules. The parents only give permission to children's use gadget only on Saturday and Sunday because the children should learn more than play games with the smartphone, they will become lazy and it will affect to their academic achievement. The participant's statements were strengthened by the resulting research from (Kordi, Abdorreza \& Baharudin, 2010), the authoritative parenting have associated with higher level's of children'school achievement. The reason why they have an association because the parents with authoritative behaviour have a perspective that academic success is valued will have children perceived more competent in academic.

Authoritative parenting has more advantages for children development and the participants can describe this advantages from their knowledge for example, the children have positive behaviour and get higher achievment. This parenting style consistently had a positive impact on psychology competence such as maturation, resilience, optimism, selfreliance, social competence, self-esteem and academic achievement. Children who grow up with authoritative parenting have less prosocial problem behaviour. The less problem behaviour on the children who get an authoritative parenting style because the parents also showed fewer conduct problems. It is can be said that if the parents want to have children behave they should behave first and using authoritative parenting (Baumrind, 1966).

From table 1. The high level of authoritative parenting gives us information that the participants still have a good quality of interaction between the children. For example, the parents make eye contact while talking, hugging, listening to the children, and give some advice to guiding the children while the children using a gadget. According to (Pempek, T. A., \& Lauricella, 2018), there is so many the effect of media exposure such as the quality and quantity of parents and child interaction will be decreased, moreover their interaction can be negatively especially interaction when they play and focused attention.

Duration for a using gadget for children with six until seven hours every week and only on Saturday and Sunday will cause addiction. According to (Fajariyah, S. N., Suryawan, A., 2018), the duration for children ages from two until five years old on using gadget every day only one hour. If the children using more than one hours it will make them addiction, even though they used with supervision from the parent and the worst they only use on weekend with the total duration of six until seven hours. It is exceeding the limit for children. The children's addiction with the gadget will be effected their development aspect and achievement on their academic. For example, the language aspect of a child will be late speech because they do not learn to communicate through interactions, although they can pronounce the word well and express the idea difficult to understand the sentence. Children who are handheld with their 30-minute gadget will tend to risk $49 \%$. 
The children's behaviour while using gadget also shows that the obey the parent's rules. They never used the gadget on the weekdays because they know that the rules that the parents provide if they disobey the rules, they will get punishment from the parents. Adhering the parent's rule when using gadget because they know the consequences can be causes the children to have good cognitive skills. Cognitive skills can be addressed with critical thinking, knows the consequences from the action being part of the cognitive skills. According to the (Temple, Ch., Steele, J., 2000), critical thinking is competence to analyze differences and comparison, similarities and differences, observing and identifying causeeffect, extracting ideas, utility, and positive or negative effect. Knowing the consequences with punishment when the children broke the rule are indicate the children develop the cognitive skill especially on critical skill.

Cognitive for children develop when they handled with the gadget, because they play games such as puzzle or scribbling. According to (M, 2018), when the children handheld with the gadget, they will get a positive impact. The children can improve the cognitive skills because they learn to process information, reasoning, remembering, and relating object with other objects during they play puzzle or scribbling or drawing on the application that is instaled at the gadget. Using gadget for children from the positive side not only increase the cognitive skill for children. Gadget are also gained some skills beside cognitive skills when handlend with gadget.

The children embed to use Youtube at the time they used gadget. With this application children have a better motor skill, cause of distraction in children, children feel fun, educating the young one, and competition skills when using the gadget. For motor skills, the aspect that can develop when playing with the gadget is linked with muscles of small movement such as lips, fingers, wrists, tongue and toes. When the children play the games they do healthy exercise that stimulant for growing up the children. Comparing with another tool, playing with gadget safer, with gadget the children cannot make the home messy like doing painting at the wall or disturbing the parents. The children also feel fun better than the other games even the play puzzle or race, or candy crush, or a simple first shooter game. Children also can develop the independent skills from playing with gadget. According to (M, 2018), The gadget also give the children to learn on their own, it will help them to perform well in their studies. And with play games with the gadget can practise them to develop competitive skills, because the children can compete with the other using the same games at the same time. Even play with gadget have some of the benefits, these activities have to use with limited access (M, 2018).

Besides the children can get positive effects (M, 2018) have arguments that gadget still has disadvantages such as attention deficits, learning problems, anxiety, depression, and negative character. When the children cannot paying attention when the parents talking, or excess activity, uncontrolling behaviour it is can be said that they have Hyperactivity Disorder (ADHD). Play with the gadget can cause this symptom and cause the children to be fidgety, unable to focus, restless and easy distracted and this can happen not only at home but also at school. Addiction with gadget also makes the children need more time to learn to communicate with the parents because there is no bond between them. For behaviour, using gadget can make the children have anxiety when they not handled with the gadget. The anxiety will make children show aggression or tense and only cure with the gadget. Play with the gadget can cause this symptom and cause the children to be fidgety, unable to focus, restless and easy distracted and this can happen not only at home but also at school. Addiction with gadget also makes the children need more time to learn to communicate with the parents because there is no bond between them. For behaviour, using gadget can make the children have anxiety when they not handled with the gadget. The anxiety will make children show aggression or tense and only cure with the gadget. The character of the children also can get affected because they never learn the moral value in real life. The wors thing that gadget makes the children depression, this mental health development in the 
children when they can know the fact and the unreal because the children only interact with the gadget.

Puzzle, Youtube, games are application that parents provides for children because the parents know those applications not only fit with their children but also gives benefit to developing an aspect of the child. Providing application does not mean the parents have full of authority to control what the children likes. The authoritative parenting identical with freedom, however, when the parents implement their parenting style they still controlling the children behaviour. For an example gives the children limited access for the application that they used. The parents still believe that the children must have a real connection with their friends in real life even though they can make a relationship through the games that they play together with the application on the gadget in the same time. Even when the parents controlling the application for the children using the gadget, they never complain because in the beginning both of them had a compromise on how to use a gadget. It shows that authoritative parenting not only can develop an aspect of children but also positive behaviour on them.

The level of understanding of parents influenced their action to embed the children's behaviour. Authoritative parenting styles have been related to building positive behaviour on the children. That positive behaviour focus on effect handled with a gadget such as a discipline, obey the parent's rule, gained critical thinking, and independent. The children's behaviour shown has the similar with authoritative parenting that the parents told on this research.

\section{CONCLUCTION}

In conclusion, the authoritative parenting style on a higher level of understanding has been described that parents know well from the knowledge, understanding, and implementation. Those aspect building positive behaviour on their child when they are handled with the gadget. The parents cultivated children with discipline only use on the Saturday and Sunday or weekend with the application that the parent provides before. The children can use the gadget two until three hours if they disobey the rule the children will get punishment. However, the authoritative parenting styles have a positive impact on their children, in this research find that the duration of using gadget have concluded have to be reduced. The maximum children handled with the gadget is one hour every day, it is better for the children to use with consecutively day than only on the weekend with the duration of more than one hour. Even a gadget is essential for communication or embraces the technology, the parents have to wiser to engage the children with a gadget. If they have to be knowledgeable about technology such as a gadget the parents should be guiding the children while using it.

\section{ACKNOWLEDGEMENT}

The authors would like to thank for financial support by SEAMEO CECCEP Southeast Asian Minister of Education Organization through Grand Reseach 2019.

\section{REFERENCES}

Baumrind, D. (1966). Effects of Authoritative Parental Control on Child Behaviour. Genetic Psychology http://arowe.pbworks.com/f/baumrind_1966_parenting.pdf

Monographs.

Bibi, F., Chaudhary, A. G., \& Tariq, B. (2013). Contribution Parenting Style in life domainof Children. IOSR Journal Of Humanities And Social Science (IOSR-JHSS), 12(2), 91-95. https:// doi.org/doi:https:// doi.org/10.9790/0837-1229195

Fajariyah, S. N., Suryawan, A., \& A. (2018). Dampak Penggunaan Gawai Terhadap Perkembangan Anak. Sari Pediatri, 2(2), 101-105. 
https://doi.org/http://dx.doi.org/10.14238/sp20.2.2018.101-5

Jahja, Y. (2015). Psikologi Perkembangan (Keempat). Prenadamedia Group. https:/ / books.google.co.id/books?id=5KRPDwAAQBAJ\&pg=PR4\&lpg=PR4\&dq=Ja hja,+Y.+(2011).+Psikologi+Perkembangan.+Edisi+Pertama.+Jakarta:+Penerbit+Kenca na.\&source=bl\&ots=DXEDTvDG_Q\&sig=ACfU3U3NRUtaVW_3OaXyUUxGqMzxXx u6fg\&hl=id\&sa=X\&ved=2ahUKEwipobCZ5_noAhVRfX0K

Kordi, Abdorreza \& Baharudin, R. (2010). Parenting Attitude and Style and Its Effect on Children's School Achievements. International Journal of Psychology Studies, 2(2), 217222. https:// doi.org/10.5539/ijps.v2n2p217

M, : Sundus. (2018). The Impact of using Gadgets on Children. Journal of Depression and Anxiety, 6(4), 269. https:// doi.org/doi:10.4172/2167-1044.1000296

Mensah, Monica Konnie \& Kuranchie, A. (2013). Influence of Parenting Styles on the Social Development of Children. Academic Journal of Interdisciplinary Studies, 2(3), 123-129. https://doi.org/10.5901/ajis.2013.v2n3p123

Miles, M. B., Huberman, M. A., \& Saldana, J. (2014). Qualitative Data Analysis: A Method Sourcebook (E. H. Salmon (ed.); Fourth Edi). SAGE Publication.

Novilia, E., Murwani, D., \& Indrawati, A. (2016). Parenting Style in Entrepreneurship Building on Children. IOSR Journal of Business and Management, 18(10), 76-81. https:/ / doi.org/10.9790/487X-1810027681

Paler, Juvert N., Batiller, Kenneth B., \& Valiente, L. (2019). Parenting Style and Task Performance of Students. International Journal of Scientific and Research Publications, 9(1), 1-6. https:// doi.org/http:/ / dx.doi.org/10.29322/IJSRP.9.01.2019.p8537

Pempek, T. A., \& Lauricella, A. R. (2018). The Effect of Parent-Child Interaction and Media Use on Cognitive Development in Infants, Toddlers, and Preschoolers. In \& P. J. B. F. C. Blumberg (Ed.), Cognitive Development in Digital Contexts (pp. 53-74). Elsevier Inc. https://doi.org/httpshttps:// doi.org/10.1016/B978-0-12-809481-5.00003-1

Pratomo, Y. (2019, May 5). APJII: Jumlah Pengguna Internet di Indonesia Tembus 171 Juta Jiwa.

Https://Tekno.Kompas.Com. https://tekno.kompas.com/read/2019/05/16/03260037/apjii-jumlah-penggunainternet-di-indonesia-tembus-171-juta-jiwa

Rogers, Maria, A., Theule J., Ryan Bruce A., Adams G. R., \& K. L. (2009). Parental Involment and Children's School Achievement. Evidence for Mediating Processes. Canadian $\begin{array}{llllll}\text { Journal of School Psychology, 24(1), } 34 & \text { - } & 57 .\end{array}$ https://doi.org/https://doi.org/10.1177/0829573508328445

Sa'ad. (2015). Dampak Penggunaan Gadget Terhadap perilaku Sosial Siswa Di MAN Cirebon 1 Kabupaten Cirebon [IAIN Syekh Nurjati]. http:/ / repository.syekhnurjati.ac.id/2126/

Sarwar, S. (2016). Influence of Parenting Style on Children's Behaviour. Journal of Education and Educational Development, 3(2), 222-249. https:// doi.org/http://dx.doi.org/10.22555/joeed.v3i2.1036

Schumacher, A., Erol, S., \& Shin, W. (2016). A Maturity Model for Assesing Industry 4.0 Readiness and Maturity of Manufacturing Enterprise. Procedia, 52, 161-166. https:/ / doi.org/https://doi.org/10.1016/j.procir.2016.07.040

Setiawati, Eka, Sohihatulmillah, Elih, Cahyono, Habib, A. D. (2018). The Effect of Gadget on Children's Social Capability. Journal of Physics: Conference Series: The 1st International Conference on Computer, Science, Engineering and Technology, 1179. https://doi.org/10.1088/1742-6596/1179/1/012113

Shikret, R., \& Vecchiotti, S. (1997). Parenting Styles, Guilt, and College Adjustment. Biennial Meeting of the Socieaty for Research in ChildDevelopment (SRCD), 1-5. http://cmtcenter.net/wp-content/uploads/2017/07/Shilkret_Vecchiotti1997.pdf

Temple, Ch., Steele, J., L. (2000). Reading and Writing for Critical Thinking Development. Gloria Publising House. 